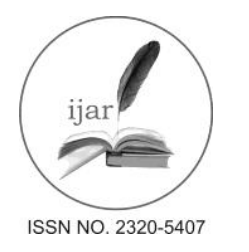

Journal homepage: http://www.journalijar.com
Journal DOI: 10.21474/IJAR01

INTERNATIONAL JOURNAL

OF ADVANCED RESEARCH

RESEARCH ARTICLE

\title{
EFFECTS OF THE GREEN MARKETING, PUBLIC POLICY AND MANAGERIAL COMMUNICATION STRATEGIES.
}

\begin{abstract}
Sonia Sharma.
Research Scholar, Department of Commerce, Sri Satya Sai University of Technology \& Medical Sciences, Sehore, Bhopal.
\end{abstract}

\section{Manuscript Info}

Manuscript History:

Received: 15 April 2016

Final Accepted: 29 May 2016

Published Online: June 2016

Key words:

green marketing, push-pull strategy, green consumer, push-pull effects, green communication strategy, quality of life enhancement, sustainable development, environment preservation

*Corresponding Author

Sonia Sharma.

\begin{abstract}
The constant degradation of the atmosphere and the bad impacts on the life quality cause several challenges for the consumer, businesses and governments. These need a new living philosophy and new solutions which must be integrated in the sustainable growth concept. The objective of this paper is to outline the specific impacts of putting into practice a novel green marketing paradigm which should formed the sustainable development problem. We underline the contribution of the push-pull strategies to the accomplishment of the dual role of the green company, of an organization with a social reason and as a business with a profit purpose. This contribution may be determined in the push-pull impacts on business, consumer, environment and sustainable development. The analysis concentrates on the push-pull green communication techniques and on the part they could play for achieving successfully push-pull impacts. These impacts go beyond the necessary meanings of marketing communication which are convincing, informing and deciding by empowering and educating the consumers with green solutions. All these impacts can be determined in the effect on the well-being of the society and consumers, on the environment, on the business and on the sustainable development. The increment of the green purchasing and consumption, the well-being enhancement, and a better benefit are the forms the push-pull impacts could take at a micro level. At a macro level, the most important impacts are the slowing of global warming, decreased water, air and soil pollution, waste energy depletion and new green energy sources, decreasing of deforestation, and depletion prevention of natural resources. These impacts are multiplied by a slower rhythm of energy resources consumption, the crude oil resources saving and other raw materials and of drinking water. The sustainable growth is backed also by ceasing the intense exploitation of the energetic resources and natural resources, and by more lasting products.
\end{abstract}

Copy Right, IJAR, 2016,. All rights reserved.

\section{Introduction:-}

The green marketing will become the 21 st century business philosophy if the concentration on sustainable growth environment preservation and a fair life quality will be managed. This new green marketing paradigm should be assumed within the evolution procedure of the green marketing. [13] Who quote think that this emergence has three phases which are the ecological green marketing, the environmental green marketing and the sustainable green marketing. The last phase became famous in the late 1990s and early 2000s and has all components of the earlier two phases but has the long term problems as a new focus. This novel paradigm of green marketing underlines the significance of social dimension within the sustainable development context as a prerequisite for the accomplishment of the company's marketing aims [11]. All these are objectives for a novel green marketing paradigm having features and elements which can harmonize the individual with the social interests with respect to a 
green philosophy [16]. First, the green marketing should have a balanced technique between technological, physical and economic parts of the society and the business. In this manner, the green marketing is actually a subset of the societal marketing which is concentrated on natural atmosphere integrated with social issues [17]. Second, a novel paradigm of green marketing assumes to lay focus upon satisfying the real and true requirements of the consumers instead getting the superficial requirements. Third, the green marketing should view upon the consumers as real human beings instead hypothetic economic entities.

\section{The Concept of Push-Pull Effects:-}

The push-pull effects as output of the green strategies:-

Each company must play a dual role, of an organization with a social reason on one hand and as a business with a gain motive thinks [3]. These two aims, social and profit, are antagonistic and for the business would be complicated to project it as performing both. For succeeding, the company should play the role of a promoter of a particular cause with the purpose of education and sensitizing the consumer about the particular issue and determining the requirements of consumers. Both aims are legal for the green companies, too. A green company should be a green cause promoter and determine the emergencies of already and powerful green consumers. This technique could be called the green push -pull initiative and it can offer severe input to the company with the profit purpose. The objective becomes a support for the growth of the green marketing that best satisfy the green consumers' requirements and it could be known as the green push- pull strategy.

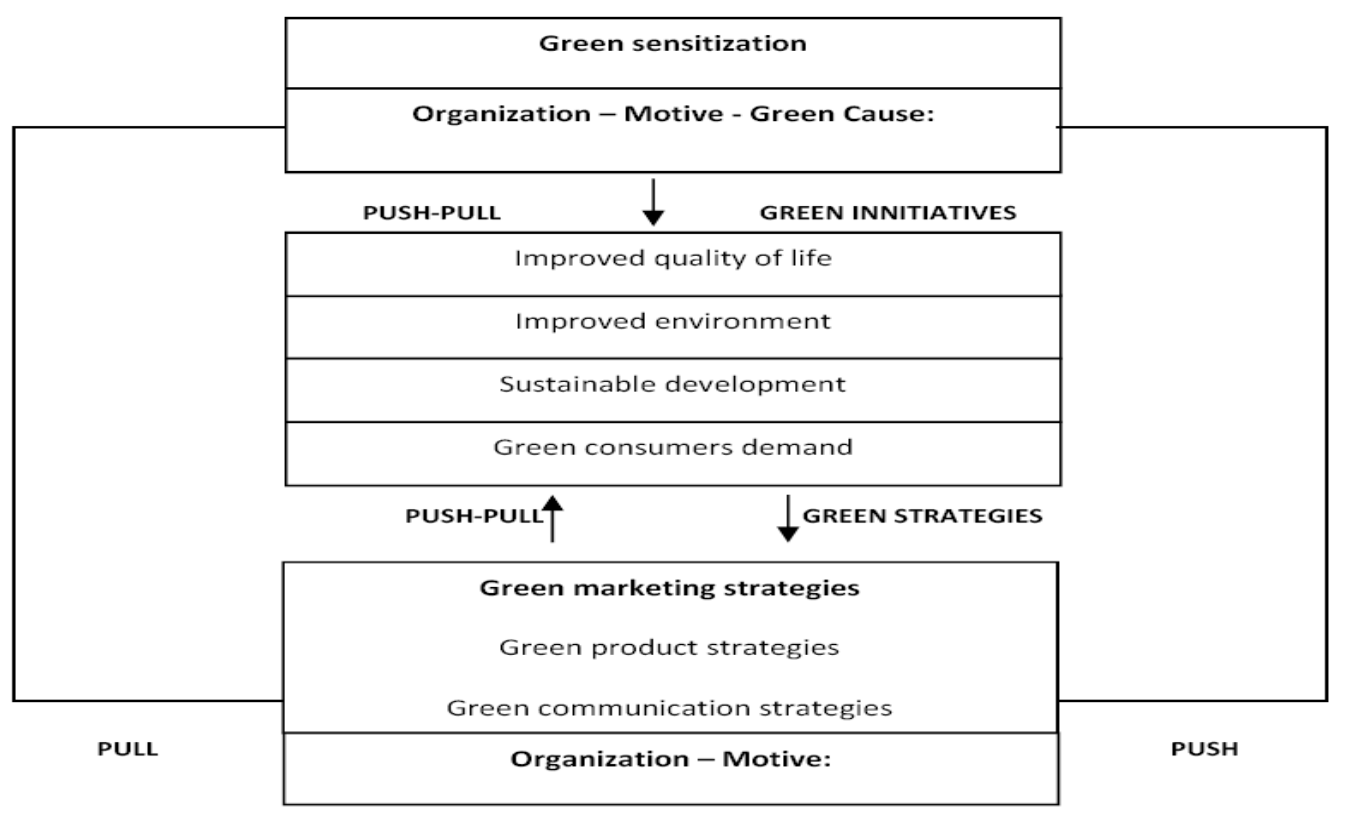

Figure 1:- The green marketing transformation and the push-pull effects.

The fig 1 shows how a green sustainable aim and a profit aim impact the green consumers in creating and fulfilling the need for green products. Consequently, the company can understand better the consumers and hence offer critical new products marketing strategy development input to the organization profit. The green marketing technique means considering the green product to consumer. This strategy type refers to the producer work or a marketer requires performing for obtaining the product to the customers. It's a proactive proceeding which includes establishing distribution channels and persuading the distributors to stock the product. This push technique can work specifically well for lower value items i.e. fast moving consumer goods when customers are standing at the self ready to drop an item into their baskets and are ready to make decisions on the spot. The new businesses usually follow a push strategy for their product for generating exposure and a retail channel Once a brand has been set up, this can be combined with a pull green marketing technique. That means getting the consumer to come to the product. As the green consumers are informed, proactive, informed, liberal, educated and have a green awareness and they actively look out the product, the pull strategy appears more suitable. A pull marketing strategy needs a highly trusted and visible brand which can be formulated through mass media advertising or similar mechanisms. If 
the customers need a product, the distribution channel members will order it. That means the need and supply in its purest form and this is the basis of a pull green marketing scheme.

\section{The Requirements for Advantageous Push-Pull Effects:-}

The increasing no. of green consumers is accomplished by a progressive stronger green awareness that represents a social dimension. Thus, the companies consider by their own will duties that are connected with the green social corporative responsibility. But only a trusted commitment can satisfy the green consumers. More and more buyers are interested in companies' commitment into several social and green sustainable projects. That's why several marketers and producers have such initiatives and reactions. Some are growing marketing true green products, but other build only minor changes and are pushing them forward as being significant. The deceiving marketing is called "green washing" that appends a new contribution of luck of trust observed by the consumers to the green companies. This green marketing is not appropriate and has no chance on the long-term. New packages and drugs having nothing new for the environment and the life protection quality are helpful for the producers and marketers interests to the degradation of the consumers. Additionally, the consumers' confusion and criticism are issues related to green marketing strategies. Thus, the strategies focused at the "reluctant consumer" are severe if the business looks to advance and reap the advantages of the green marketing schemes. All strategic attempts are considering as true to the same extent they succeed. The green strategies are successful if they represent a strong and constant commitment for the creative substitution of classic solutions with better green alternatives. A simulation of successful green strategies must be worked out according to the $4 \mathrm{C}$ concept that is Credibility, Competency, Commitment, and Cooperation. Any green scheme has more chances for good push-pull effects if all competent, fit actors work together for the same purpose.

\section{The leading part of the green communication strategies for best push-pull effects:-} Two main balancing roles of the green communication:-

The green marketing communication has a powerful promotional substance. This means that the green promotion media, supports and messages must satisfy the public and consumers to accept and to buy the green products. Thus, it stimulates the need for green products. Furthermore, the objective of the promotional communication is to generate and to enhance the green image of the business and its offer. For achieving these significant objectives, the green communication plays an important part in correcting the trust deficit of the green marketing and the green information asymmetries. The consumers and the public are usually skeptical about the green initiatives and business schemes. Hence, appears that not the economical, technical issues, saving or obstacles for having green products but rather the business' capability to satisfy the price sensitive customers to select green products has more meaning for them. Another objective that recommends good green communication is the green communication asymmetries. The business has to understand that the public and the consumers are beneficiaries and partners and meeting their green emergencies is the most significant objective and the business survival source. This calls for an interactive green communication and for human, financial and managerial attempts. Assuming the unbalanced distribution and access to information among consumers, business and public is the latest task to satisfy the consumers that its green efforts are real. These attempts are aimed at a more balanced information flow and a correction of the asymmetries in green communication between the market's actors and their nature. A good outcome of the green communication motivates the green consumers and business.

\section{The green push-pull communication strategies:-}

The effectiveness of the strategy effects on the conviction power of the green communication. In the green marketing literature the following three green communication techniques: educate consumer, empowered consumer and convince consumer. The educate consumer technique means educative attempts on environmental and life issues a green solve as a reply to the consumers pressures or as a result of the business initiative by offering the required information. The specific objective of educative messages is the increasing of buying intent. The technique of empowering consumer with green solutions consists in developing to the consumers how environmentally healthy services and products can help them protect life and preserve the atmosphere for the future generations. Hence, this communication strategy provides support to the sustainable character of the green marketing. The above specified communication techniques have a pull or a push orientation. A conceptual model of the push- pull communication techniques as those shown in Fig 2 can support a better understanding of these directions. 

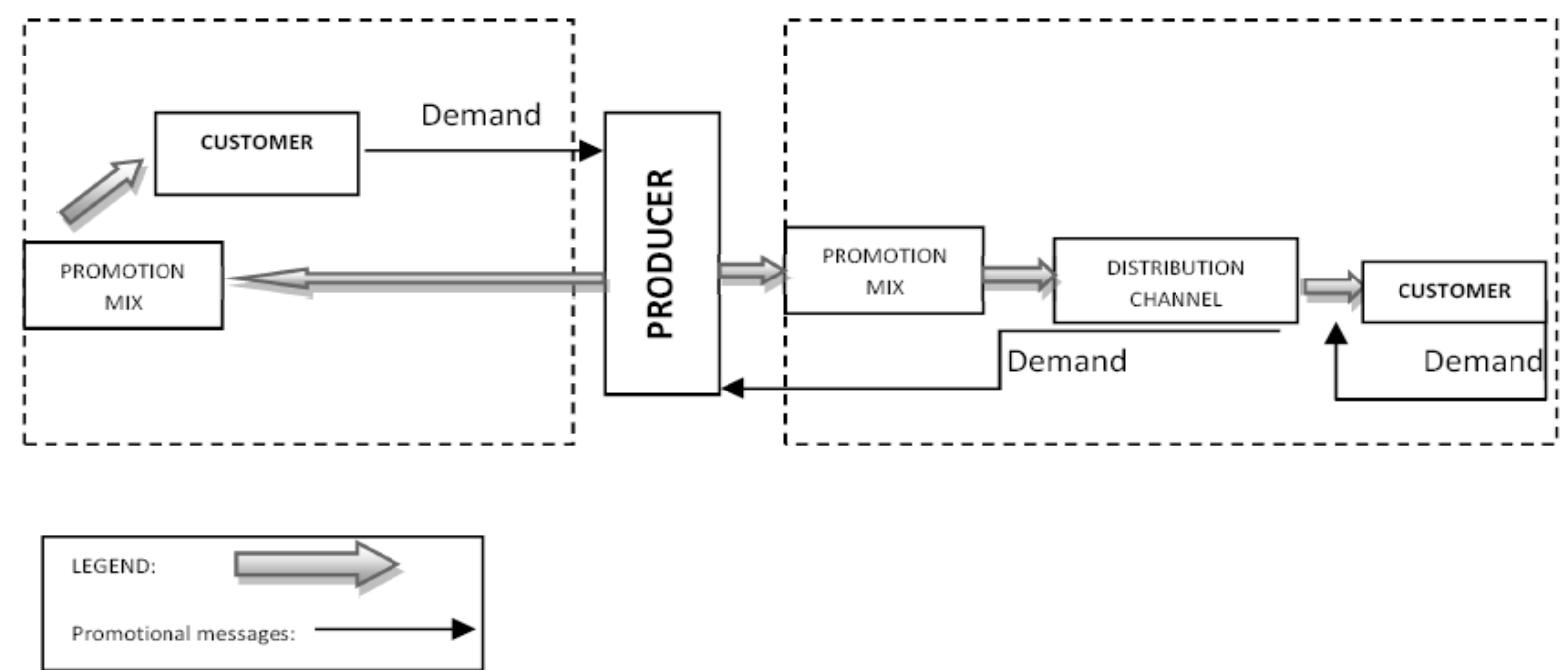

Figure 2:- The 'push-pull' promotion strategic model.

The push communication techniques have the information flow from the producers to the successive connections of the distribution channel until the message arrive the consumer and she or he need the green product as Fig 2 indicates. The implicit and explicit messages arrives the consumers through pull and push promotional mixes. The green promotion mix with impacts could have several combinations between the direct selling to consumers face to face or in show rooms, the negotiation with retailers to stock the company's product, the use of effective supply chains permitting retailers efficient supply, the trade show promotions to motivate the purchase and the point of sales displays. The pull green communication techniques have the first step on the consumers which actively view the company product as a support. The communication messages are flowing the market and the generation of requirement almost looks after itself. Some pull promotional combinations could be made from the mass media and advertising, the customer relationship management, the word of mouth referrals and sales promotions and discounts. The business must have a powerful brand, for obtaining good push-pull effects of its green marketing techniques.

\section{The push-pull effects of the green communication strategies:-}

The push-pull effects on the consumers:-

The green communication strategies have multiple and different effects. All three green communication strategies are targeting not only at the performance of the necessary roles of the marketing promotion which are convincing, informing and deciding. They go beyond that by empowering and educating the consumer with green solutions. One push-pull effect the communication techniques have is the enhancing of the green purchasing and consumption. The green communication techniques that have in view the consumer education could have specific good effects making simpler for them to select free.

\section{The push-pull effects on the quality of life:-}

The life quality is a term utilized to measure the general well- being of the societies and individuals. In a wide understanding, the life quality is " a multidimensional construct involving emotional, physical, social, mental and behavioral components. A same approach has [23] elaborates the idea of quality of life as "a wide-ranging concept incorporating in a complex manner the person's psychological state, physical health, social relationship, level of independence, personal beliefs, and their relationships to prominent characteristics of the environment". The communication techniques have an effect on the psychological and physical well-being of the society and consumers. The green communication media provides supports and messages have push-pull effects on the societal and individual well-being by better information utilizing more confirm argumentation that is satisfying the consumers to purchase green products and the business to build green investments. These impacts take shape if the available and new green brands are stressed, the contributions of the marketing practices to decrease the pollution, preserving fauna and for enhancing the longevity, the housing and the health are outlined. 


\section{The push-pull effects on the business:-}

The green strategies have several advantages for the business with green marketing practices. First of all, these strategies build simpler a better profitability because the green products produce less waste, utilize less raw materials, save energy. Then, the green products are greater in quality with respect to performance, energy saving, safety or convenience. The organic products provide safety and a better taste, the recycled plastic or paper save money whereas the solar-power cell phones have an extended usage and waste reduction. A quiet ride, decreased population, fewer fill-ups and status are some advantages of the hybrid cars. The green communication should concentrate on such impacts and focus them in the promotional messages, for contributing to

better impacts on the green targets of the business. The third, the companies which are first to deliver their green inventions to the market enjoy competitive benefits and increased market share, at a specific extent. But increasing the market share is the attribute of a better brand loyalty. The consumers look the company's record on the atmosphere as a significant determinant of their purchase decision. The green communication has a specific role in reporting the consumers on the true character of the company and its brand.

\section{The push-pull effects on the environment:-}

The environment derives several advantages from the green marketing techniques, the communication strategy involved. A well-coordinated green communication technique could contribute to a better physical atmosphere. The beneficial impacts are a slowing global warming, decreased water, air and soil pollution, new sources of energy and waste energy depletion, decreased deforestation, natural resources depletion, and a better landfills rate. To all those advantages could be added a slower rhythm of resources and energy consumption, saving the resources of oil and other raw materials, extinction of endangered species, drinking water and they must be utilized in the argumentation of the communication tactics.

\section{The push-pull effects on the sustainable development:-}

If the novel green marketing paradigm is combined into the sustainable development concept, the outcome of the green communication techniques and practices could contribute to the fulfilling of the present and without compromising the capability of future generations to satisfy their requirements. The good impacts indicate themselves both at the macro level and at the micro level of the sustainable development. The green product is a subject of fulfilling the aim associated to the contribution to the sustainable development. The sustainable product technique has an effect on ceasing the intensive exploitation of the energetic resources and the natural resources. The perishable raw materials could be substituted by more lasting others, on one side. On the other side, the renewable resources can be more utilized as is the case of the substitution of crude oil with wind or solar sources for producing electric energy. All green products are more sustainable if they are more lasting. The durability becomes an added value source, an indicator for quality and leads to a reduced consumption of raw materials.

\section{Conclusions:-}

The disorder of the Earth's ecosystem which is a result of the mankind unfortunate actions needs powerful and intelligent steps to fight back for managing its entropy. The green marketing can formulate a no. of strategies which support the attempts for the environment preservation and the enhancement of the life quality. For getting the best results, a new green marketing paradigm which represents several areas of actions i.e. its contribution on sustainable development and environment protection in addition to the efforts for companies and consumers. The successful implementation of this specific mechanism should have the issue of the push-pull effects. They are the outputs of the green techniques execution which have a push-pull character. A pull strategy is getting the consumer come to the product and a push green strategy means taking the product to the consumer. The push-pull communication techniques are a part of the green techniques that support the effort to obtain the best push-pull effects. These impacts are distributed among consumers, environment, business and sustainable development. As the business is the primary part of the green efforts, its push-pull green techniques and effects based on how they comply with all needs and concepts of the new green marketing paradigm. Ottman proposes that the business has to achieve various conditions, for getting the best push-pull effects. First, the business has to understand the deeply held social and environmental values and beliefs of its consumers. Second the business must generate new marketing strategies which could balance the consumers' needs for green quality, affordability and convenience with minimal environmental and maximal social and sustainable impact over the life quality. The third, the business must be capable to develop brands that provide practical advantages while engaging and empowering the consumers in meaningful manners about the important green issues. Fourth, the business requires to set up credibility for its efforts by communicating its corporate commitment and attempting for complete transparency. Fifth, the business 
has to think in a holistic way that is it must underscore community with the wide array of corporate societal and environmental stakeholders. Sixth, the business is compelled to be proactive and must go beyond what is required from stakeholders. At last, the business should not giving up and must promote responsible the green product usage and disposal practices and seamlessly attempting for "zero" impact. The contribution of the business, the push-pull effects of its green communication strategies involved, in fulfilling all needs and acquiring its dual role, of an organization with a social reason and as a business with a profit aim, is conducted only if the green techniques are worked out and implemented in a professional way and with goodwill.

\section{References:-}

1. Baumann, H., Boons, F., Bragd, A. (2002), "Mapping the green product development field: engineering, policy and business perspectives", Journal of Cleaner Production, Vol. 10 pp.409-25.

2. Bolton, R.N. (1998), "A dynamic model of the duration of the customer's relationship with a continuous service provider: the role of satisfaction", Marketing Science, Vol. 17 No.1, pp.45-65

3. Cadotte, Ernest R., Robert B. Woodruff and Roger L. Jenkins (1987), "Expectations and Norms in Models ofConsumer Satisfaction," Journal of Marketing Research, 24 (August), 305-314

4. Cope, D., Winward, J. (1991), "Information failures in green consumerism", Consumer Policy Review, Vol. 1 No.2, pp.83-6.

5. Cronin, J.J., Brady, M.K., Hult, T.M.G. (2000), "Assessing the effects of quality, value, and customer satisfaction on consumer behavioral intentions in service encounters", Journal of Retailing, Vol. 76 No.2, pp.193-218

6. Churchill, Gilbert A. Jr. and Carol Surprenant (1982), "An Investigation into the Determinants of Customer Satisfaction," Journal of Marketing Research, 19 (November), 491 -504.

7. Day, Ralph L. (1977), "Towards a Process Model of Consumer Satisfaction," Conceptualization and Measurement of Consumer Satisfaction and Dissatisfaction. H. Keith Hunt, ed. Cambridge, MA: Marketing Science Institute, 153-183.

8. Fuller, D.A. (1999), Sustainable Marketing, Sage Publications, Thousand Oaks, CA.

9. Hines, J.M., Hungerford, H.R., Tomera, A.N. (1987), "Analysis and synthesis of research on responsible environmental behavior: a meta-analysis", Journal of Environmental Education, Vol. 18 pp.1-8

10. Hopfenbeck, W. (1993), Dirección y Marketing Ecológicos, Ediciones Deusto, Madrid,

11. Isherwood, K. (2000), Mineral Fertilizer Distribution and the Environment, International Fertilizer Industry Association, UNEP, Paris, March.

12. Jaime Rivera-Camino, (2007) "Re-evaluating green marketing strategy: a stakeholder perspective", European Journal of Marketing, Vol. 41 Iss: 11/12, pp.1328 - 1358

13. Jones, M.A., Suh, J. (2000), "Transaction-specific satisfaction and overall satisfaction: an empirical analysis", Journal of Services Marketing, Vol. 14 No.2, pp.147-5.

14. Kinnear, T.C., Taylor, J.R., Ahmed, S.A. (1974), "Ecologically concerned consumers: who are they?" Journal of Marketing, Vol. 38 No.April, pp.20-4.

15. Ottman, J. (1998), Green Marketing: Opportunity for Innovation, 2nd ed., NTC/Contemporary Books, Lincolnwood.

16. Ottman, J., Terry, V. (1998), "Strategic marketing of greener products", The Journal of Sustainable Product Design, Vol. 5 No. April, pp.53-7.

17. McIntosh, A. (1990), "The impact of environmental issues on marketing and politics in the 1990s", Journal of the Marketing Research Society, Vol. 33 No.3, pp.205-17.

18. Menon, A., Menon, A. (1997), "Enviropreneurial marketing strategy: the emergence of corporate environmentalism as market strategy", Journal of Marketing, Vol. 61 No. January, pp.51-67. 640

19. Polonsky, M., Ottman, J. (1998a), "Exploratory examination of whether marketers include stakeholders in the green new product development process", Journal of Cleaner Production, Vol. 6 No.3, pp.269-75.

20. Pujari, D., Wright, G., Peattie, K. (2003), "Green and competitive: influences on environmental new product development performance", Journal of Business Research, Vol. 56 No.8, pp.657-71.

21. Page, N., Eddy, C. (1999), "The correlation between service quality, satisfaction and loyalty", Australian \& New Zealand Marketing Academy Conference, University of New South Wales School of Marketing, Sydney

22. Patterson, P.G., Johnson, L.W., Spreng, R.A. (1997), "Modelling the determinants of customer satisfaction for business-to-business professional services", Journal of the Academy of Marketing Science, Vol. 25 No.1, pp.417

23. Pickett, G.M., Kangun, N., Grove, S.J. (1995), "An examination of the conserving consumer: implications for public policy formation in promoting conservation behavior", in Polonsky, M.J., Mintu-Wimsatt, A.T. 
(Eds),Environmental Marketing: Strategies, Practice, Theory, and Research, The Haworth Press, New York, NY, pp.77-99.

24. Stone, G., Barnes, J.H., Montgomery, C. (1995), "Ecoscale: a scale for the measurement of environmentally responsible consumers", Psychology \& Marketing, Vol. 12 No.7, pp.595-612.

25. [25] Swenson, M.R., Wells, W.D. (1997), "Useful correlates of pro-environmental behavior", in Goldberg, M.E., Fishbein, M., Middlestadt, S.E. (Eds), Social Marketing, Theoretical and Practical Perspectives, Lawrence Erlbaum,Mahwah, NJ, pp.91-109

26. Traylor, M. (1981), "Product involvement and brand commitment", Journal of Advertising Research, Vol. 21 pp.51-6

27. Varadarajan, R., Menon, A. (1988), "Cause-related marketing: a coalignment of marketing strategy", Journal of Business Research, Vol. 31 No.2, pp.93-105

28. Woodruff, Robert B., Ernest R. Cadotte and Roger L. Jenkins (1983), "Modelling Consumer Satisfaction Processes Using Experience-Based Norms," Journal of Marketing Research, 20 (August), 296-304

29. Yi, Youjae (1990), "A Critical Review of Consumer Satisfaction," in Review of Marketing. Valerie A. Zeithaml, ed., Chicago: American Marketing Association, 68-123. 